\title{
ANALYSIS ON LATERALLY LOADED GROUP PILES BY PLAXIS 3D FOUNDATION
}

\author{
Sri Dewi; Gouw Tjie-Liong \\ Civil Engineering Department, Faculty of Engineering, Binus University \\ Jl. K.H. Syahdan No. 9, Palmerah, Jakarta Barat 11480 \\ gouw2007@gmail.com
}

\begin{abstract}
ABSTRAK
Telah lama dikenal bahwa kapasitas lateral group tiang lebih kecil dari penjumlahan kapasitas lateral dari masing-masing tiang. Untuk menentukan kapasitas lateral efektif group tiang, diperlukan faktor reduksi yang dikenal juga dengan nama faktor efisiensi. Sepanjang pengetahuan penulis, dalam buku-buku text geoteknik hanya jarak antar tiang yang diperhitungkan terhadap kapasitas lateral group. Faktor modulus kekakuan tanah dan jumlah total tiang dalam satu group tidak pernah diperhitungkan. Penelitian ini ditujukan untuk mencari pengaruh dari faktor-fator tersebut dalam kapasitas lateral tiang. Penelitian menggunakan perangkat lunak Plaxis 3D Foundation, yaitu perangkat lunak element hingga 3D khusus geoteknik. Hasil penelitian menunjukan bahwa semakin banyak jumlah tiang dalam satu group tiang semakin kecil faktor efisiensi kapasitas lateral group tiang tersebut, dan semakin besar kekakuan tanahnya semakin besar faktor efisiensinya.
\end{abstract}

Kata kunci: faktor efisiensi, kapasitas lateral grup tiang, Plaxis 3D Foundation.

\begin{abstract}
It has been known that a group pile lateral capacity is smaller than the sum of each pile capacity composing the group. A reduction factor, also known as efficiency factor, is required to determine the effective lateral capacity of group piles. To the authors' knowledge, in most geotechnical text books, only the spacing of piles is considered in evaluating the pile group lateral capacity. No consideration on the effects of soil stiffness modulus and the total number of piles forming the group is taken into account. This research tried to investigate the influence of those factors by using geotechnical 3D finite element software, namely Plaxis 3D foundation. It is found that the bigger the number of piles in a group, the lower the efficiency factor is; the higher the soil stiffness modulus, the greater the efficiency is.
\end{abstract}

Keywords: efficiency factor, group pile lateral capacity, PLAXIS 3D Foundation 


\section{INTRODUCTION}

Apart from axial loads, lateral loads induced by wind, earthquakes, berthing of ships, vehicle acceleration and braking forces on the bridges, etc, have to be taken into account in designing a foundation system. Therefore, determination of the lateral capacity of pile foundation is one of the utmost important in foundation engineering.

It is well understood that a group pile lateral capacity is smaller than the sum of each pile capacity composing the group. A multiplier is required to determine the effective lateral capacity of group piles. The multiplication factor is known as group efficiency factor or reduction factor. In the available geotechnical text books, the only factor considered in determining the reduction factor is the center-to-center spacing of the piles.

To the authors' knowledge, no in-depth study has been carried out to investigate the influence of the total number of piles forming the group and the effects of soil stiffness on the said efficiency factor. To answer whether there is any influence of these factors on the carrying capacity of the laterally loaded group pile - under the supervision of the second author - the first author carried out numerous analyses by using Plaxis 3D Foundation software version 2.2.

Due to time constraints, the extend of the study is limited to the following scope: (1) only $1 \mathrm{~m}$ diameter bored pile of 40 meter length is considered; (2) the center-to-center spacing of piles considered are 4D, 5D and 6D, where $\mathrm{D}$ is the diameter of the pile; (3) in evaluating the effect of pile spacing, the numbers of piles taken into account in a group are 4, 9, 16, 25, 36, 49 and 64 piles; (4) the value of soil stiffness ranges from $3000 \mathrm{kN} / \mathrm{m}^{2}$ to $25000 \mathrm{kN} / \mathrm{m}^{2}$; (5) in evaluating the effect of soil stiffness modulus, the numbers of piles considered in a group are 2, 4, 6, 9, 12, 25, 36, 49 and 64; (6) no existence of axial load; (7) pile head deflection is limited to $6 \mathrm{~mm}$; (8) no pile cap effect is considered; (9) only fixed head capacity of piles is considered. As the present Plaxis version cannot determine the single pile fixed head capacity; the pile single pile capacity of pile is determined from finite difference method.

\section{Literature Review}

There are numerous methods available in determining the lateral capacity of a single pile, e.g. Reese Matlock method, Chang method, finite difference method, etc. From all the available methods, only finite difference method can directly evaluate the pile lateral carrying capacity of layered soils without going through the averaging of the horizontal sub grade reaction coefficient. Therefore, this method is adopted in determining the lateral capacity of a single pile.

\section{Finite Difference Method}

Winkler (1867) stated that the reaction force of a laterally loaded pile is proportional to the displacement. Pressure (P) and deflection (y) are related through the coefficient of horizontal subgrade reaction $\left(\mathrm{k}_{\mathrm{h}}\right)$,

$$
\mathrm{P}=\mathrm{k}_{\mathrm{h}} \cdot \mathrm{y}
$$

The pile is considered as a thin rod which satisfies the following equation:

$$
E_{p} \cdot I_{p} \cdot \frac{d^{4} y}{d z^{4}}=-P \cdot B
$$

where:

$E_{p} \quad=$ Modulus elasticity of pile

$I_{p} \quad=$ Moment inertia of pile 
Z = Depth

$B \quad=$ Diameter of pile

Combining equation (1) and (2),

$$
E_{p} \cdot I_{p} \cdot \frac{d^{4} y}{d z^{4}}+k_{h} \cdot B \cdot y=0
$$

The solution to the above differential equation can be obtained either analytically or numerically. An analytical solution is easy to obtain when the value of $k_{h}$ is constant throughout the pile. When the value of $k_{h}$ varies with depth, a numerical solution by finite difference method is employed (Palmer and Thompson, 1948; Gleser, 1953).

In this method, the basic differential equation (3) is written in the form of finite difference as follows:

$$
\begin{aligned}
& E_{p} I_{p}\left(\frac{y_{i-2}-4 y_{i-1}+6 y_{i}-4 y_{i+1}+y_{i+2}}{\delta^{4}}\right) \\
& +\left(k_{h} \cdot B \cdot y_{i}\right)=0
\end{aligned}
$$

Equation (4) leads to:

$$
\mathrm{y}_{\mathrm{i}-2}-4 \mathrm{y}_{\mathrm{i}-1}+\alpha_{\mathrm{i}} \mathrm{y}_{\mathrm{i}}-4 \mathrm{y}_{\mathrm{i}+1}+\mathrm{y}_{\mathrm{i}+2}=0
$$

with:

$$
\alpha_{i}=6+\frac{k_{h i} \cdot L^{4} \cdot B}{E_{p} \cdot I_{p} \cdot n^{4}}
$$

where:

$n \quad=$ number of interval throughout the pile

$k_{h i}=$ Coefficient of horizontal subgrade reaction at point $i$.

Figure 1 below shows the finite difference method for laterally loaded pile.

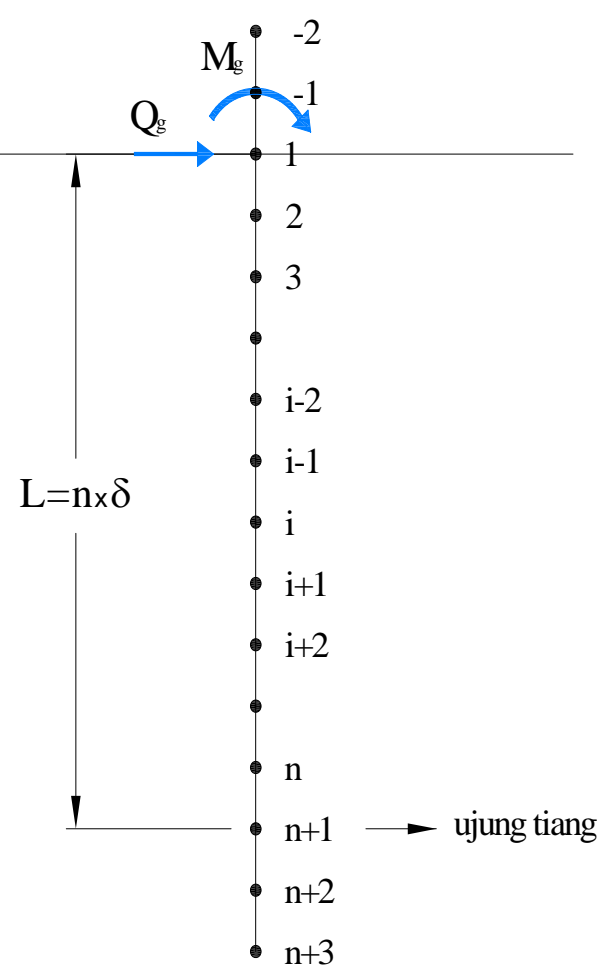

Figure 1. Finite difference method for laterally loaded pile. 
A total simultaneous equation $n+5$ is needed to calculate the $n+5$ displacement which is unknown at the point (-2, $-1, n+2$ and $n+3)$. Equation (6) can be employed from point 2 to point $n$ in order to provide $(n-1)$ equations. Further equations can be obtained from boundary conditions at the pile head. At the pile head there are two conditions to consider, i.e. free head and fixed head conditions.

Free head pile

Shear force:

$$
E_{p} \cdot I_{p} \cdot \frac{d^{3} y}{d z^{3}}=Q_{g}
$$

thus:

$$
-y_{-2}+2 y_{-1}-2 y_{2}+y_{3}=\frac{Q_{g} \cdot L^{2}}{E_{p} \cdot I_{p} \cdot n^{3}}
$$

Moment:

$$
E_{p} \cdot I_{p} \cdot \frac{d^{2} y}{d z^{2}}=M_{g}
$$

hence:

$$
\mathrm{y}_{2}-2 \mathrm{y}_{1}+\mathrm{y}_{-1}=\frac{\mathrm{M}_{\mathrm{g}} \cdot \mathrm{L}^{2}}{\mathrm{E}_{\mathrm{p}} \cdot \mathrm{I}_{\mathrm{p}} \cdot \mathrm{n}^{2}}
$$

Fixed head pile

Shear force:

$$
E_{p} \cdot I_{p} \cdot \frac{d^{3} y}{d z^{3}}=Q_{g}
$$

thus:

$$
-y_{-2}+2 y_{-1}-2 y_{2}+y_{3}=\frac{Q_{g} \cdot L^{2}}{E_{p} \cdot I_{p} \cdot n^{3}}
$$

Rotation:

$$
E_{p} \cdot I_{p} \cdot \frac{d y}{d z}=0
$$

hence:

$$
\mathrm{y}_{2}-\mathrm{y}_{-1}=0
$$

The pile tip is considered free, so:

Shear Force at pile tip:

$$
E_{p} \cdot I_{p} \cdot \frac{d^{3} y}{d z^{3}}=0
$$

hence:

$$
-y_{n-1}+2 y_{n}-2 y_{n+2}+y_{n+3}=0
$$

Moment at pile tip:

$$
E_{p} \cdot I_{p} \cdot \frac{d^{2} y}{d z^{2}}=0
$$

hence:

$$
\mathrm{y}_{\mathrm{n}}-2 \mathrm{y}_{\mathrm{n}+1}+\mathrm{y}_{\mathrm{n}+2}=0
$$


Two more required equations are obtained from equilibrium condition of horizontal force and moment.

Another way to solve the above is to ignore the shear force equation at the pile end (tip) and the pile head (top), i.e., equations (8) or (12) and (16). Therefore, ignore the two displacement variables at the point -2 and $n+3$. In this case only $n+3$ equations have to be solved. This procedure gives similar results to the previous procedure.

\section{Group Pile Analysis}

To find the lateral capacity of the group pile, Prakash in 1962 (Poulos, 1980) proposed to reduce the value of coefficient of horizontal sub grade reaction $\left(k_{h}\right)$, as shown in Figure 2. The group pile can then be performed using the finite difference method described earlier by entering reduced $k_{h}$ values.

\section{METHOD}

\section{Modeling in Plaxis 3D}

Plaxis 3D Foundation is a three-dimensional Plaxis program, developed for the analysis of three dimensional foundation and geotechnical problems. It is part of the Plaxis suite finite element software used worldwide for geotechnical engineering design. The software allows the complex finite element model to be solved quickly. The various available output facilities can be used to display the detail computational results. In this study the effect of pile cap is not considered. To eliminate friction between the soil and the pile cap, a dummy soil of $10 \mathrm{~cm}$ thick beneath the pile cap is introduced in the modeling (Figure 3). The dummy soil has the characteristics of water, so as to eliminate the friction.

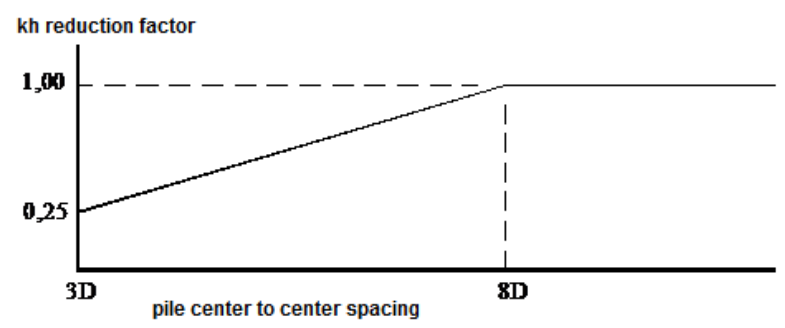

Figure 2. Group pile reduction proposed by Prakash in 1962 (Poulos, 1980).

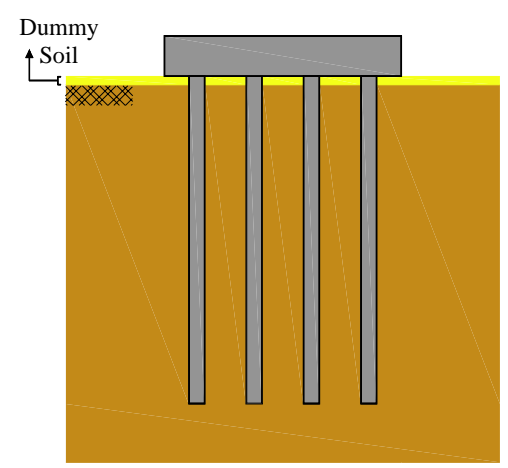

Figure 3. Plaxis 3D Foundation Modeling. 

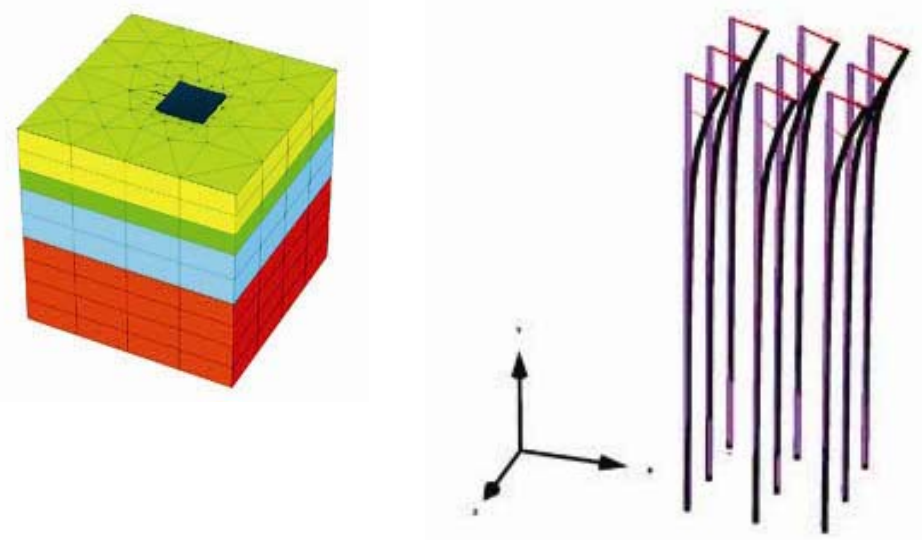

Figure 4. Output of plaxis 3d foundation for the group of 9 piles

\section{The Input Parameters}

Pile parameter:

Diameter $\quad=1 \mathrm{~m}$

Length $\quad=40 \mathrm{~m}$

$\mathrm{E}_{\mathrm{p}}=2,59 \times 10^{7} \mathrm{kN} / \mathrm{m}^{2}$

Table 1

Soil Parameters

\begin{tabular}{ccccc}
\hline Soil & MH 1 & MH 2 & MH 3 & MH 4 \\
\hline Depth (m) & $0-12$ & $12-18$ & $18-33$ & $33-60$ \\
$\gamma_{\mathrm{d}}\left(\mathrm{kN} / \mathrm{m}^{3}\right)$ & 11 & 10 & 11 & 13 \\
$\gamma_{\text {sat }}\left(\mathrm{kN} / \mathrm{m}^{3}\right)$ & 17 & 16 & 17 & 18 \\
$\mathrm{E}\left(\mathrm{kN} / \mathrm{m}^{2}\right)$ & 8000 & 14000 & 20000 & 25000 \\
$\mathrm{c}\left(\mathrm{kN} / \mathrm{m}^{2}\right)$ & 10 & 15 & 20 & 25 \\
$\phi$ & $21^{\circ}$ & $22^{\circ}$ & $25^{\circ}$ & $25^{\circ}$ \\
\hline
\end{tabular}

\section{RESULTS AND DISCUSSION}

The results of the study are presented in Table 2 and Figure 5 and 6 below.

Table 2

Lateral Capacity of Single Pile Based on Finite Difference

\begin{tabular}{ccc}
\hline \multirow{2}{*}{ Method } & \multicolumn{2}{c}{ Lateral Capacity } \\
\cline { 2 - 3 } & Free Head Pile & Fixed Head Pile \\
\hline Finite Difference & $124 \mathrm{kN}$ & $215 \mathrm{kN}$ \\
\hline
\end{tabular}




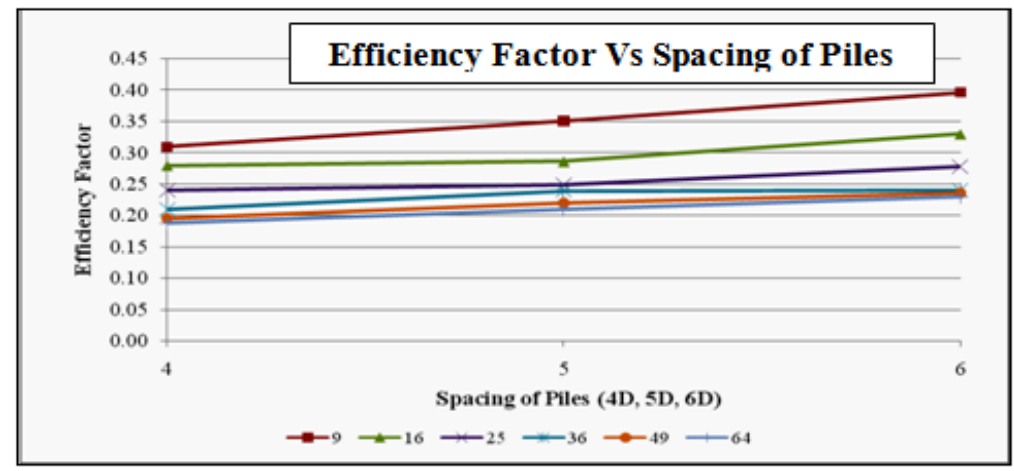

Figure 5. Efficiency factor vs. pile spacing (center to center) based on Plaxis analysis.

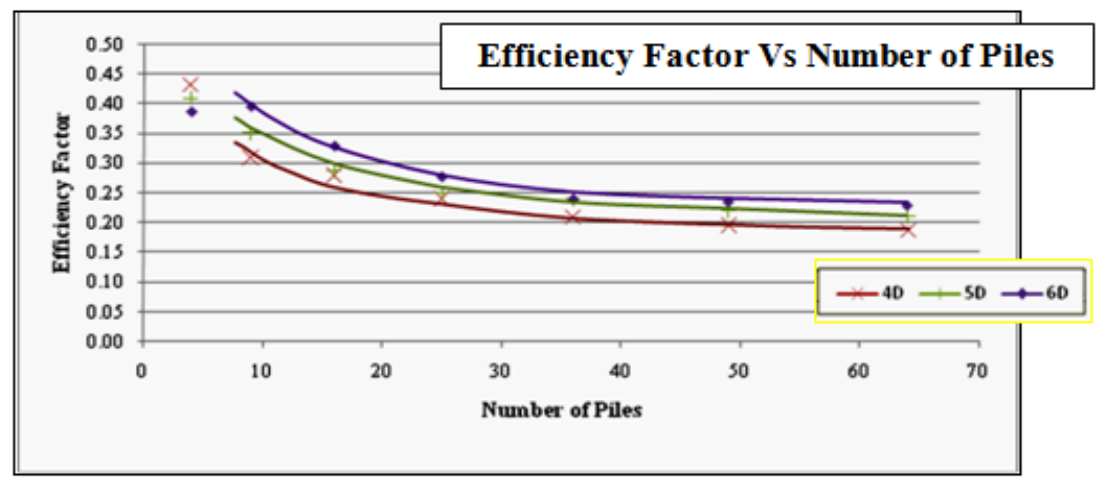

Figure 6. Efficiency factor vs. number of piles based on Plaxis analysis.

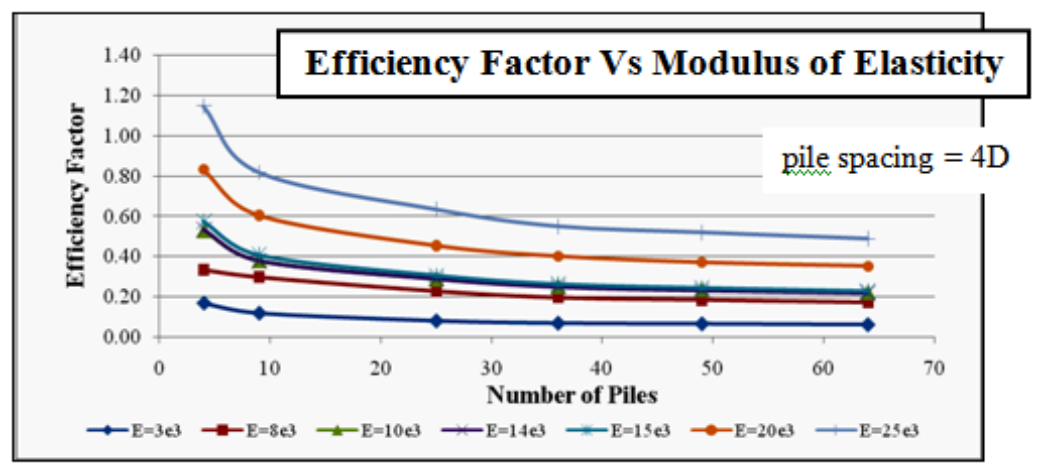

Figure 7. Influence of soil stiffness modulus for symmetrical pile configuration; $\mathrm{E}=$ Soil Stiffness Modulus in $\mathrm{kN} / \mathrm{m}^{2}$

\section{CONCLUSION}

Based on the analysis using Plaxis 3D Foundation program, it is found out that the spacing and the number of piles, as well as the soil stiffness do have significant effects to the lateral capacity of group pile. The conclusions are summarized below: (1) the greater the spacing between piles in a group pile, the greater the efficiency factors are. This is due to the fact that the reaction area of the soil 
behind each pile is larger. Therefore, the interaction region among the piles (i.e. the overlapping reaction areas) becomes smaller. Hence, the lateral capacity of the group pile becomes greater; (2) the total number of piles in a group has significant influence on the efficiency factor of the group pile. The greater the number of piles in a group pile, the lower the efficiency factor is; giving the lowest efficiency factor to around 0.20; (3) the stiffness modulus of the soil also affects the efficiency factor of the group pile. The efficiency factor increases a long with the higher stiffness modulus of the soil.

The above is the interim results of the study. To make the study complete, the following shall be investigated further: (1) pile spacing of 2, 3, 7 and 8 times pile diameter; (2) various pile lengths and diameter; (3) pile cap effects; (4) comparative study by using different geotechnical finite element program, such as the GeoStudio or other.

\section{REFERENCES}

Gouw, T. L. (2007). Materi Kuliah Teknik Pondasi. Jakarta: Universitas Bina Nusantara.

Gouw, T. L. (2008). Materi Kuliah Aplikasi Komputer Dalam Teknik Sipil. Jakarta: Universitas Bina Nusantara.

Gouw, T. L., Usmanto \& Natalius, K.W. (1984). Studi Pressuremeter Menard dan Oyo Serta Aplikasinya Dalam Daya Dukung. Bandung: Universitas Katolik Parahyangan.

PLAXIS b.v. (2002). PLAXIS 3D Foundation Version 2.0. Netherlands: A.A. Balkema Publisher.

Poulos, H.G. dan Davis, E.H. (1980). Pile Foundation Analysis and Design. New York: John Wiley \& Sons. 